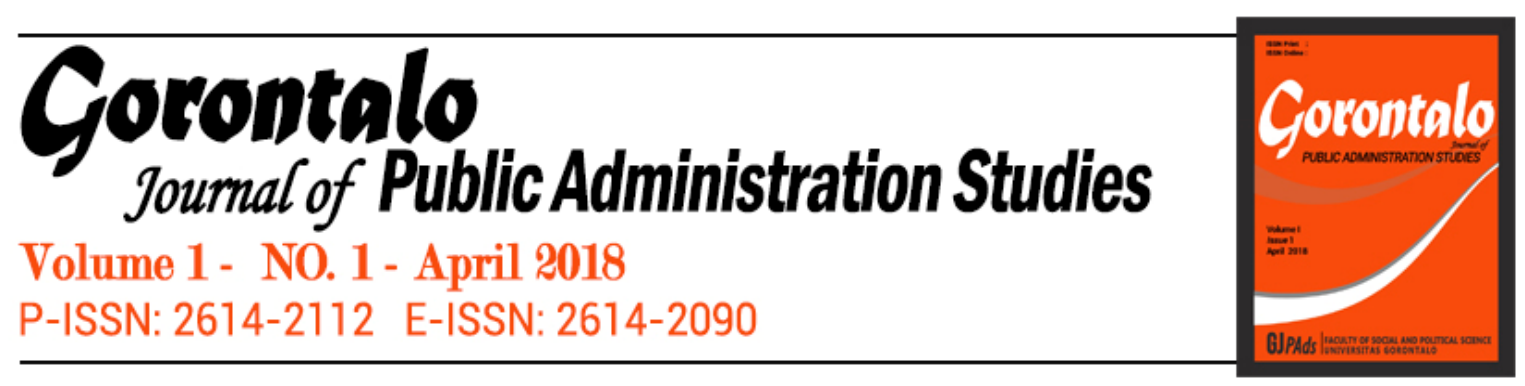

\title{
Pengaruh Kepemimpinan Transformasional terhadap Peningkatan Kualitas Kinerja Pegawai di Dinas Pendidikan Kabupaten Bone Bolango
}

\author{
Abdul Wahab Podungge \\ Universitas Negeri Gorontalo \\ Podunggewahab@gmail.com
}

\begin{abstract}
This study aims to determine the influence of transformational leadership on employee performance in Education Office of Bone Bolango District (Dinas Pendidikan Kab. Bone Bolango). The method used is quantitative, reinforced with the processed statistical data with the dispersion questionnaire. The data obtained came from interviews, observation, literature study, and documentation. The result of the research shows that there are influence of transformational leadership on the performance of the employees in Education Office of Bone Bolango District as follows: a) There is a direct positive and significant influence simultaneously between transformational leadership variables on employee performance in Education Office of Bone Bolango District . b) There is a direct positive and significant influence between the idealized leadership variable (influence ideal) partially on the performance of employees at Education Office of Bone Bolango District. c) There is a direct positive and significant influence between leadership variables inspiration motivation partially on the performance of employees at the Education Office of Bone Bolango District. d) There is a direct positive and significant influence between leadership variables partial intellectual stimulation on employee performance in Education Office of Bone Bolango District. e) There is a positive and significant direct influence between individual leadership considerations partially on employee performance in Education Office of Bone Bolango District.
\end{abstract}

Keywords: leadership; employee performance; Bone Bolango.

\section{ABSTRAK}

Penelitian ini bertujuan untuk mengetahui pengaruh kepemimpinan transformasional terhadap kinerja karyawan di Dinas Pendidikan Kabupaten Bone Bolango (Dinas Pendidikan Kab. Bone Bolango). Metode yang digunakan adalah kuantitatif, diperkuat dengan data statistik yang diolah dengan penyebaran kuesioner. Data yang diperoleh berasal dari wawancara, observasi, studi pustaka, dan dokumentasi. Hasil penelitian menunjukkan bahwa ada pengaruh kepemimpinan transformasional terhadap kinerja pegawai di Dinas Pendidikan Kabupaten Bone Bolango sebagai berikut: a) Terdapat pengaruh langsung positif dan signifikan secara simultan antara variabel kepemimpinan transformasional terhadap kinerja karyawan di Dinas Pendidikan. Kabupaten Bone Bolango. b) Ada pengaruh langsung positif dan signifikan antara variabel kepemimpinan ideal (pengaruh ideal) secara parsial terhadap kinerja karyawan di Dinas Pendidikan Kabupaten Bone Bolango. c) Ada pengaruh positif dan signifikan langsung antara variabel kepemimpinan motivasi inspirasi secara parsial terhadap kinerja karyawan di Dinas Pendidikan Kabupaten Bone Bolango. d) Ada pengaruh positif dan signifikan langsung antara variabel kepemimpinan rangsangan intelektual parsial terhadap kinerja karyawan di Dinas Pendidikan Kabupaten Bone Bolango. e) Ada pengaruh langsung positif dan signifikan antara pertimbangan kepemimpinan individu secara parsial terhadap kinerja karyawan di Dinas Pendidikan Kabupaten Bone Bolango.

Kata Kunci: kepemimpinan; kinerja karyawan; Bone Bolango. 


\section{PENDAHULUAN}

Untuk mendukung pembangunan pemerintahan yang berkelanjutan, dibutuhkan kinerja aparat yang berkompeten. Kinerja adalah tingkat sejauh mana keberhasilan seseorang di dalam melaksanakan tugas pekerjaannya kinerja merupakan suatu subjek permasalahan tersendiri, di mana kinerja sering diarahkan sebagai suatu indeks dari sesuatu yang lain, seperti pelajaran dan dorongan Kinerja pelayanan sebagaimana dicetuskan melalui semangat desentralisasi dan debirokratisasi, pada kenyataannya masih menunjukkan tingkatan yang belum optimal. Desentralisasi yang berarti pelimpahan kewenangan pengurusan penyelenggaraan pemerintahan ke level yang lebih rendah, dan debirokratisasi yang berarti efisiensi dan fleksibilitas dalam pelaksanaan pelayanan masyarakat, masih belum menunjukkan adanya perubahan dari pola sebelumnya. Sistem kerja aparatur pemerintah daerah, khususnya tingkat instansi yang terlalu birokratis, dan kurang tanggap terhadap kebutuhan pelayanan, mengisyaratkan masih belum meresapnya pemahaman perubahan paradigma penyelenggaraan pemerintahan.

Demikian halnya dengan eksistensi Provinsi Gorontalo yang mendedikasikan untuk membangun daerah yang berdaya saing dengan memanfaatkan potensi sumber daya yang memiliki meliputi sumber daya manusia, daya dukung alam, ilmu pengetahuan dan teknologi demi peningkatan kesejahteraan masyarakat.

Dalam hal ini menuntut adanya pemerintahan provinsi yang mandiri yang dapat mengembangkan inovasi,kreatifitas,spirit entrepreneur serta lebih responsif terhadap kepentingan publik dan mudah diakses oleh masyarakat. Dengan begitu,jarak antara pemerintah dan masyarakat menjadi semakin dekat yang memungkinkan kinerja pelayanan masyarakat (public service) menjadi lebih baik sehingga akselerasi pembangunan dan ekonomi daerah dalam rangka meningkatkan kesejahteraan masyarakat akan mudah dicapai. Harapan diatas membutuhkan sarana yang dapat memediasi atau mebantu kinerja pemerintah dalam konteks penyelenggaraan pemerintahan dan pembangunan di Provinsi Gorontalo khususnya di Kabupaten Bone Bolango.

Terdapat hubungan yang erat antara kinerja perorangan dengan kinerja lembaga.Dengan perkataan lain kinerja pegawai baik maka kemungkinan besar kinerja lembaga juga baik, kinerja seorang pegawai akan baik bila dia mempunyai keahlian (skill) yang tinggi,bersedia bekerja bila di gaji,mempunyai harapan masa depan lebih baik.Keberhasilan organisasi dengan ragam kerja tergantung pada kinerja pegawai.Unsur manusialah yang memegang peranan yang sangat penting dan menentukan keberhasilan mencapai tujuan organisasi.

Tuntutan terselenggaranya good governance dalam implementasi penerapan otonomi daerah, tidak sekedar tuntutan yuridis formil, tetapi lebih dari itu adalah bukti nyata adanya tuntutan atas peningkatan kinerja pegawai. Hal ini telah berdampak pada pergeseran paradigma manajenen sektor publik (pemerintah), khususnya dipemerintah daerah yang telah mengarah kepada perwujudan pemerintah demokratis, responsive, akuntabel, serta peningkatan organisasi pemerintah untuk mencapai tujuan organisasi.

Tuntutan tersebut semakin besar dalam beberapa tahun terakhir dengan pemberian kewenangan yang lebih luas bagi Pemerintah Kota dan Kabupaten seiring dengan diberlakukannya Undang-Undang Nomor 23 Tahun 2014 tentang pemerintahan daerah yakni dasar dari penyelenggaraan otonomi daerah adalah kinerja dengan efektif,efisien, transparan, dan memiliki akuntabilitas yang tinggi. 
Daerah tidak dapat mengembangkan diri atas dasar tersebut, pada gilirannya akan menuai ketidakmampuan pengelolaan sumber dayanya dan tentu saja akan berakhir pada kemunduran sosial, ekonomi, dan politik masyarakat.

Dari hasil observasi awal peneliti tentang penerapan gaya kepemimpinan yang berjalan di dinas pendidikan kabupaten bone bolango adalah Pemimpin mempuyai tanggung jawab menciptakan kondisi-kondisi dan perangsangperangsang yang memotivasi anggota mencapai tujuan yang ditentukan. Motivasi atau dorongan dapat berdampak pada perilaku positif yaitu memberikan semangat kerja ataupun berdampak negatif yaitu tekanan. Gaya kepemimpinan seseorang sangat berpengaruh terhadap kemampuan seseorang dalam mempengaruhi individu atau kelompok, agar perilaku bawahan sesuai dengan tujuan organisasi, maka harus ada perpaduan antara motivasi akan pemenuhan kebutuhan mereka sendiri dan permintaan organisasi. Hanya saja instruksi yang di jalankan pimpinan tidak semuanya berjalan dengan efektif. Hal ini ditandai dengan masih ada beberapa pegawai yang tidak bekerja dengan maksimal dalam menjalankan tugasnya sebagai apatur sipil negara. Beberapa diantaranya dapat dilihat dari absensi pegawai yang sering bolos kerja, dan keluar kantor disaat jam kerja dengan alasan yang kurang jelas sehingga menghabat pekerjaan dan menurunnya kualitas dan kuantitas dari penyelenggaraan pelayanan publik. fungsi seorang pimpinan adalah sebagai katalis dan fasilitator dari proses inovasi. Mereka menciptakan konteks untuk memilih orang-orang yang relevan, membantu mereka untuk mengatasi hambatan, dan mempercepat realisasi visi mereka.

Dari hasil pengamatan ini, peneliti menyadari bahwa segala kelebihan dan kekurangan yang ada dalam organisasi merupakan hal yang lumrah dalam lingkungan organisasi. Orang yang tidak terbiasa berpacu untuk menyesuaikan tanggung jawab, kemampuan dan meningkatkan keterampilan masih nampak dalam lingkungan mereka. Faktor sumber daya manusialah yang menjadi pembeda atas kemampuan dan motivasi setiap pegawai. Tidak semua pegawai memiliki kapasitas yang sama dalam mengerjakan setiap tugas dan tanggung jawab yang dibebankan kepada mereka. Tidak semua pegawai memiliki kemauan dan motivasi untuk tumbuh dan berkembang, dan tidak semua pegawai mampu meningkatkan kinerjanya.

Permasalahan lain yang dihadapi adalah tingginya absensi pegawai selama 4 bulan terakhir, yang menunjukkan bahwa tingkat absensi pegawai meningkat dari bulan Mei dengan jumlah 9 orang meningkat menjadi 16 orang dalam bulan Agustus. Hal ini mengakibatkan rendahnya kinerja pegawai di Dinas Pendidikan Kabupaten Bone Bolango karena menurunnya pelayanan publik. Menurut Sedarmayanti (2011:71) kinerja pegawai dikatakan menurun apabila persentase absensi di atas 10\%. Berikut ini tingkat absensi pegawai selama 4 bulan terakhir: 
Tabel 1.1 Tingkat absensi pegawai 4 bulan terakhir

\begin{tabular}{|c|c|c|c|c|c|}
\hline \multirow[b]{2}{*}{ Bulan } & \multicolumn{3}{|c|}{ Absensi } & \multirow[b]{2}{*}{ Jumlah } & \multirow[b]{2}{*}{ Persentasi } \\
\hline & Izin & Sakit & $\begin{array}{l}\text { Tanpa } \\
\text { kabar }\end{array}$ & & \\
\hline Mei 2015 & 4 & 3 & 2 & 9 & $1,8 \%$ \\
\hline Juni 2015 & 5 & 3 & 4 & 12 & $2,4 \%$ \\
\hline Juli 2015 & 5 & 5 & 3 & 13 & $2,6 \%$ \\
\hline $\begin{array}{l}\text { Agustus } \\
2015\end{array}$ & 8 & 3 & 5 & 16 & $3,2 \%$ \\
\hline
\end{tabular}

\section{Sumber: Data primer Dinas Pendidikan Kabupaten Bone Bolango 2015}

Berdasarkan wawancara yang telah dilakukan, ternyata lingkungan kerja dinas pendidikan kabupaten bone bolango bersifat positif namun masih ada beberapa permasalahan yang harus dihadapi manajemen. Permasalahan di organisasi muncul ketika pemimpin kurang melakukan pengawasaan terhadap perkembangan kinerja bawahannyaa meskipun pemimpin sudah berupaya menekankan dan mengarahkan pentingnya tujuan organisasi. Namun tidak semua pegawai mampu mentransformasikan apa yang dikehendaki pimpinan, tidak semua pegawai mampu mengaplikasikan pekerjaan dengaan baik. Permasalahan inidapat berakibat buruk terhadap menurunnya kinerja pegawai. Oleh karena itu, untuk mengetahui sejauh mana kinerja para pegawai, pimpinan perlu mengetahui bagaimana perilaku pegawainya. Pemimpin harus mempunyai kemampuan yang baik dalam memimpin organisasi seperti:pemimpin harus proaktif dalam pemikirannya, lebih radikal, inovatif dan kreatif serta lebih terbuka terhadap ide-ide baru (Avolio dalam sutikno 2014:99). Tanpa kemampuan seperti itu, pegawai tidak akan mau mendengarkannya, karena pemimpin harus dapat menggugah respek para pegawai. Dari sinilah perlu adanya suatu penilaian kepemimpinan, mengenai bagaimana para pegawai menilai kepemimpinan dari pemimpin mereka dengan melalui sudut pandang yang berbeda-beda.

Terlepas dari keragaman manusia dilihat dari kemampuan dan motivasinya untuk tumbuh dan berkembang, hal ini merupakan keharusan yang tidak dapat ditawar lagi. Karena kebutuhan dan tuntutan pekerjaan terus mengalami perubahan sejalan dengan dinamika kebutuhan dalam kemajuan ilmu pengetahuan dan teknologi, tuntutan akan keterampilan-keterampilan baru, memiliki motivasi dan inovasi, tuntutan percepatan waktu kerja, dan keragaman pekerjaan yang harus diselesaikan. Berangkat dari sinilah permasalahan organisasi muncul.

Kepemimpinan merupakan suatu konsep yang sangat dekat dengan kesuksesan dalam mencapai tujuan suatu organisasi. Kepemimpinan adalah ilmu atau kemampuan dalam menggunakan pengaruh terhadap orang lain untuk mencapai tujuan organisasi atau usaha kerja sama. Kepemimpinan akan sangat mewarnai, mempengaruhi bahkan menentukan bagaimana perjalanan suatu organisasi dalam mencapai tujuan - tujuannya. Pemimpin adalah orang orang yang tahu apa yang harus dikerjakan, memiliki kemampuan dan kelebihan yang melebihi kemampuan orang lain, mempunyai kecakapan, kemampuan untuk mawas diri, kemampuan mengajak, membimbing, fasilitator bagi orang lain, memberi motivasi orang lain. Selain itu juga harus memiliki 
kemampuan untuk mampu membina orang lain untuk membentuk satu kesatuan kerja dan bersama sama mereka bekerja, dan bahkan rela berkorban demi tercapainya tujuan yang telah ditetapkan (Sutikno 2014:25).

Model kepemimpinan yang dinilai pegawai melekat terhadap pimpinannya di dinas pendidikan kabupaten bone bolango adalah kepemimpinan transformasional. Robert house, dalam Sutikno (2014:54) menyampaikan bahwa kepemimpinan yang efektif menggunakan dominasi, memmiliki keyakinan diri, mempengaruhi dan menampilkan moralitas yang tinggi untuk meningkatkan kharismatiknya. Dengan kharismanya pemimpin transformasional akan menantang bawahan untuk melahirkan karya istimewanya. Pemimpin transformasional akan membujukpara bwahannya melakukan tugas-tugas mereka melebihi kepentingan mereka sendiri demi kepentingan organisasi yang lebih besar. Pemimpin transformasional mencoba menimbulkan kesadaran pengikut dengan mengarahkannya kepada cita-cita dan nilai moral yang tinggi. Akan tetapi tidak semua pegawai memiliki kemampuan dan motivasi yang sama terhadap arahan pimpinannya. Hal inilah yang menarik untuk dijadikan bahan penelitian.

\section{KAJIAN TEORI}

\subsection{Kinerja}

Sinambela, dkk (2012:136), mengemukakan bahwa kinerja pegawai didefinisikan sebagai kemampuan pegawai dalam melakukan sesuatu keahlian tertentu. Kinerja pegawai sangatlah perlu, sebab dengan kinerja ini akan diketahui seberapa jauh kemampuan pegawai dalam melaksanakan tugas yang dibebankan kepadanya. Untuk itu diperlukan penentuan kinerja yang jelas dan terukur serta ditetapkan secara bersama-sama yang dijadikan sebagai acuan.

Jika disimak berdasarkan etimologinya, kinerja berasal dari kata performance. Performance berasal dari kata "to perform" yang mempunyai beberapa masukan (entris): (1) memasukkan, melaksanakan, menjalankan; (2) memenuhi atau menjalankan kewajiban suatu nazar; (3) menggambarkan suatu karakter dalam suatu permainan; (4) menggambarkan dengan suatu suara atau alat musik; (5) melaksanakan atau menyempurnakan tanggung jawab; (6) melakukan suatu kegiatan dalam suatu permainan; (7) memainkan musik; (8) melakukan sesuatu yang diharapkan oleh seseorang atau mesin (Rivai, 2005: 2). Rivai, (2005:14).

Tidaklah semua masukan tersebut relevan dengan kinerja disini, hanya empat saja yakni: (1) melakukan; (2) memenuhi atau menjalankan; (3) melaksanakan suatu tanggungjawab, dan (4) melakukan sesuatu yang diharapkan oleh seseorang. Dari masukan tersebut dapat diartikan bahwa kinerja adalah pelaksanaan suatu pekerjaan dan penyempurnaan pekerjaan tersebut sesuai dengan tanggungjawabnya sehingga dapat mencapai hasil sesuai dengan yang diharapkan. Definisi ini menunjukkan bahwa kinerja lebih di tekankan pada proses, dimana selama pelaksanaan pekerjaan tersebut diakukan penyempurnaan-penyempurnaan sehingga pencapaian hasil pekerjaan atau kinerja dapat dioptimalkan.

Faktor-faktor yang dapat mempengaruhi pencapaian kinerja adalah Faktor kemampuan (ability) dan faktor motivasi (motivation). Mitchel dalam Sinambela $(2012: 9)$ : 


\section{Kemampuan}

Secara psikologis, kemampuan terdiri dari kemampuan potensi (IQ) dan kemampuan realita, artinya karyawan yang memiliki IQ yang rata-rata (IQ 110-120) dengan memadai untuk jabatannya dan terampil dalam mengerjakan pekerjaannya sehari-hari, maka ia akan lebih mudah mencapai kinerja yang diharapkan oleh karena itu karyawan perlu ditempatkan pada pekerjaan yang sesuai dengan keahliannya.

2. Motivasi Kerja

Motivasi terbentuk dari sikap (Attitude) seorang karyawan dalam menghadapi situasi kerja. Motivasi merupakan kondisi yang menggerakkan diri karyawan yang terarah untuk mencapai tujuan organisasi (tujuan kerja). Sikap mental merupakan kondisi mental yang mendorong diri pegawai untuk berusaha mencapai prestasi kerja secara maksimal. (Sikap mental yang siap secara psikofik) artinya, seorang karyawan harus siap mental, mampu secara fisik, memahami tujuan utama dan target kerja yang akan dicapai, mampu memanfaatkan dalam mencapai situasi kerja.

\subsection{Kepemimpinan Transformasional}

Burns (1978) dalam buku Sutikno (2014:53) berpandangan bahwa kepemimpinan transformasional sebagai sebuah proses dimana "para pemimpin dan pengikut saling menaikkan diri ke tingkat moralitas dan motivasi yang lebih tinggi". Menurut Burns, kepemimpinan transformasional dapat diperlihatkan oleh siapa saja dalam organisasi pada jenis posisi apa saja. Karakteristik utama kepemimpinan transformasional ini diantaranya memiliki kemampuuan untuk bertindak sebagai agen perubahan (agent of change) bagi organisasi, sehingga dapat menciptakan strategi-strategi baru dalam mengembangkan praktikpraktik organisasi yang relevan. Burns (1978) menyatakan bahwa model kepemimpinan transformasional ada hakekatnya menekan seorang pemimpin perlu memotivai para bawahannya bertanggung jawab lebih dari yang diharapkan. Pemimpin transformasional harus mampu mendefinisikan, mengkomunikasikan, mengartikulasikan visi organisasi, dan bawahan harus menerima kredibilitas pemimpinnya.

Avolio dan Bass dalam Sutikno (2014:54) mengemukakan bahwa kepemimpinan transformasional mempunyai empat dimensi yang disebutnya sebagai "the four is" dimensi itu diantranya:

1) Idealized Influence (pengaruh ideal). Dimensi yang pertama ini digambarkan sebagai perilaku pemimpin yang membuat para pengikutnya mengagumi, menghormati, dan sekaligus mempercayainya.

2) Motivasi Inspirasi. Dalam dimensi ini pemimpin transformasional digambarkan sebagai pemimpin yang mampu mengartikulasikan pengharapan yang jelas terhadap prestasi bawahan, mendemonstrasikan komitmennya terhadap seluruh tujuan organisasi, dan mampu mengunggah spirit tim dalam organisasi melalui penumbuhan antusiasme dan optimisme.

3) Stimulasi Intelektual. Dalam dimensi ini pemimpin transformasional harus mampu menumbuhkan ide-ide baru, memberiikann solusi kreatif terhadap berbagai permasalahan yang dihadapi bawahan, dan memberikan motivasi kepada bawahan untuk mencari pendekatan-pendekatan yang baru dalam melaksanakan tugas-tugas organisasi.

4) Konsiderasi Individu. Dalam dimensi ini pemimpin transformasional digambaran sebagai pemimpin yang mau mendengarkan dengan penuh 
perhatian masukan-masukan bawahan dan secara khusus mau memperhatikan kebutuhan-kebutuhan bawahan terhadap pengembangan karir.

\section{METODOLOGI PENELITIAN}

Dalam penelitian ini peneliti menggunakan jenis penelitian kuantitatif menggunakan metode survey dengan pendekatan analisis jalur (path analysis). Sebagaimana dikemukakan oleh Sugiyono (2008:8) bahwa penelitian kuantitatif adalah metode penelitian yang berlandaskan pada filsafat positivisme, digunakan untuk meneliti pada populasi atau sampel tertentu, pengumpulan data menggunakan instrumen penelitian, analisis data bersifat kuantitatif/statistik, dengan tujuan untuk menguji hipotesis yang teah ditetapkan.

Sejalan dengan Effendi dalam Riduwan, (2009: 65) mengatakan bahwa penelitian survey adalah penelitian yang mengambil sampel dari suatu populasi dan menggunakan kuisioner sebagai alat pengumpulan data yang pokok. Dalam penelitian ini variabel yang dimaksud adalah kepemimpinan transformasional dan kinerja. Penentuan jumlah informan yang akan digunakan bukan pada kuantitasnya. Data yang diperoleh akan lebih valid jika informan yang dipilih berasal dari seluruh pegawai kantor dinas pendidikan Kabupaten Bone Bolango.

\section{HASIL PENELITIAN DAN PEMBAHASAN}

\subsection{Kepemimpinan Transformasional (X) secara simultan berpengaruh positif dan signifikan terhadap Kinerja Pengawai(Y).}

Temuan penelitian yang dapat dikemukakan adalah adanya pengaruh langsung yang postif dansignifikan secara simultan antara variabel Kepemimpinan Transformasional (X) terhadap Kinerja Pegawai (Y) sebesar 0,912 atau 91,2\%.Hal ini menunjukan bahwa semakin di tingkatkannya Kepemimpinan Transformasional yang dilakukan pimpinan maka semakin meningkatkan pula Kinerja pegawai yang ada pada Dinas Pendidikan Kabupaten Bone Bolango.

Hal ini disebabkan karena pimpinan yang ada di Dinas Pendidikan Kabupaten Bone Bolango senantiasa berperilaku yang membuat bawahannya mengagumi, menghormati, dan sekaligus mempercayainya, mampu mengartikulasikan pengharapan yang jelas terhadap prestasi bawahan, mendemonstrasikan komitmennya terhadap seluruh tujuan organisasi, dan mampu mengunggah spirit tim dalam organisasi melalui penumbuhan antusiasme dan optimisme yang tinggi, menumbuhkan ide-ide baru, memberikan solusi kreatif terhadap berbagai permasalahan yang dihadapi bawahannya, dan memberikan motivasi kepada bawahannya untuk mencari pendekatan-pendekatan yang baru dalam melaksanakan tugas-tugasnya, selain itu pimpinan mau mendengarkan dengan penuh perhatian masukan-masukan bawahannya dan secara khusus mau memperhatikan kebutuhan-kebutuhan bawahannya terhadap pengembangan karir. Namun masih terdapat variabel luar yang ikut mempengaruhi kinerja pegawai akan tetapi tidak dimasukan dalam model sebesar 0,088 atau $8,8 \%$.

Hal tersebut sejalan dengan pendapat Burns (1978) dalam buku Sutikno (2014:53) yang berpandangan bahwa kepemimpinan transformasional sebagai sebuah proses dimana "para pemimpin dan pengikut saling menaikkan diri ke 
tingkat moralitas dan motivasi yang lebih tinggi". Menurut Burns, kepemimpinan transformasional dapat diperlihatkan oleh siapa saja dalam organisasi pada jenis posisi apa saja. Karakteristik utama kepemimpinan transformasional ini diantaranya memiliki kemampuan untuk bertindak sebagai agen perubahan (agent of change) bagi organisasi, sehingga dapat menciptakan strategi-strategi baru dalam mengembangkan praktik-praktik organisasi yang relevan. Burns (1978) juga menyatakan bahwa model kepemimpimpinan transformasional pada hakekatnya menekankan seorang pemimpin perlu memotivasi para bawahannya bertanggung jawab lebih dari yang diharapkan. Pemimpin transformasional harus mampu mendefinisikan, mengkomunikasikan, mengartikulasikan visi organisasi, dan bawahan harus menerima kredibilitas pemimpinnya.

Penelitian ini sejalan dengan penelitianAnikmah (2008) yang mana hasil penelitiannya menunjukkan bahwa kepemimpinan transformasional berpengaruh positif terhadap kinerja karyawan PT. Jati Agung Arsitama. Hal ini terbukti dari hasil uji t memperoleh t-hitung sebesar 4,223 diterima tarraf signifikansi 5\% $(\mathrm{p}<0,05)$ dan $\mathrm{H} 1$ diterima. Artinya semakin baik kepemimpinan transformasional yang dijalankan, maka kinerja karyawannya akan meningkat.

\subsection{Idealized Influence $\left(\mathrm{X}_{1}\right)$ Berpengaruh Positif dan Signifikan terhadap Kinerja Pegawai (Y).}

Berdasarkan dari hasil penelitian terhadap 57 responden menunjukan bahwa secara parsial terdapat pengaruh langsung yang positif dan signifikan antara variabel Idealized influence $\left(\mathrm{X}_{1}\right)$ terhadap Kinerja Pegawai $(\mathrm{Y})$ sebesar 0,689 atau $68,9 \%$. Hal ini menunjukan bahwa semakin ditingkatkan Idealized influence $\left(\mathrm{X}_{1}\right) \mathrm{yang}$ dilakukan oleh pimpinan maka akan semakin meningkat pula Kinerja Pegawai (Y) pada Dinas Pendidikan Kabupaten Bone Bolango. Hal ini dikarenakan perilaku pemimpin pada Dinas Pendidikan Kabupaten Bone Bolangoselalu membuat para pengikutnya mengagumi teknik kepemimpinan kepala Dinas Pendidikan Kabupaten Bone Bolango, selalu menghormati masukan dan kritikan bawahannya, dan adanya sikap yang saling mempercayai antara atasan dan bawahan.

Hal ini sejalan dengan pendapat yang mengatakan bahwaPemimpin dalam organisasi diharapkan memiliki kemampuan mengelola sumber daya organisasi secara professional. Salah satu caranya adalah melakukan pembagian tugas yang proporsional dan menempatkan bawahannya meenurut bidang keahlian masing-masing. Menurut Avolio dkk (Stone et al, 2004) Idealized influence mempunyai makna bahwa seorang pemimpin transformasional harus kharisma yang mampu "menyihir" bawahan untuk bereaksi mengikuti pimpinan. Dalam bentuk konkrit, kharisma ini ditunjukan melalui perilaku pemahaman terhadap visi dan misi organisasi, mempunyai pendirian yang kukuh, komitmen dan konsisten terhadap setiap keputusan yang telah diambil, dan menghargai bawahan. Dengan kata lain, pemimpin transformasional menjadi role model yang dikagumi, dihargai, dan diikuti oleh bawahannya.

Idealized influence menurut Sarros dan Santora (2001) merupakan perilaku (behavior) yang berupaya mendorong bawahan untuk menjadikan pemimpin mereka sebagai panutan (role model). Pada mulanya, dimensi ini dinamakan karisma, namun karena mendapat banyak kritik maka istilah karisma diubah menjadi pengaruh ideal atau visi. Aspek kritikal karisma adalah kekuatan 
spiritual (transcendent power) yang diyakini oleh bawahan dimiliki oleh pemimpinnya, sehingga bawahan percaya sepenuhnya dan mau melakukan apa saja demi pemimpinnya (true believer). Aspek tersebut tidak dimiliki oleh setiap orang dan selama ini tidak tercakup dalam kajian kepemimpinan transformasional, sehingga dimensi ini tidak tepat disebut karisma. Kajian mengenai dimensi ini lebih terpusat pada pemimpin yang memiliki visi jauh kedepan dan mampu menanamkan visi tersebut dalam diri bawahan (Rafferty \& Griffin, 2004).

Lebih jauh, pemimpin yang mempunyai idealized influence selain mampu mengubah pandangan bawahan tentang apa yang penting untuk dicapai pada saat ini maupun masa mendatang (visi), juga mau dan mampu berbagi resiko dengan bawahan, teguh dengan nilai, prinsip, dan pendiriannya, sehingga bawahan percaya, loyal, dan menghormatinya (Bass et.al., 2003; Humphreys, 2002; Sarros \& Santora, 2001; Yammarino et.al., 1993).

Idealized influence merupakan dimensi terpenting kepemimpinan transformasional karena memberikan inspirasi dan membangkitkan motivasi bawahan (secara emosional) untuk menyingkirkan kepentingan pribadi demi pencapaian tujuan bersama (Humphreys, 2002; Rafferty \& Griffin, 2004).

\subsection{Motivasi Inspirasi (X2) Berpengaruh Positif dan Signifikan terhadap Kinerja Pegawai (Y).}

Berdasarkan dari hasil penelitian terhadap 57 responden menunjukan bahwa secara parsial terdapat pengaruh langsung positif dan signifikan antara variabel motivasi inspirasi $\left(\mathrm{X}_{2}\right)$ terhadap kinerja pegawai $(\mathrm{Y})$ sebesar 0,334 atau $33,4 \%$. Hal ini menunjukan bahwa semakin ditingkatkan motivasi inspirasi $\left(\mathrm{X}_{2}\right)$ yang dilakukan oleh pimpinan maka akan semakin meningkat pula pula kinerja pegawai (Y) pada Dinas Pendidikan Kabupaten Bone Bolango. Hal ini dikarenakan kepala dinas Pendidikan Kabupaten Bone Bolango mampu mengartikulasikan pengharapan yang jelas terhadap prestasi bawahannya, selalu mendemonstrasikan komitmen terhadap seluruh tujuan yang ingin dicapai oleh dinas Pendidikan Kabupaten Bone Bolango, dan mampu mengunggah spirit tim dalam organisasi melalui penumbuhan antusiasme dan optimisme yang tinggi terhadap bawahannya.

Menurut Avolio dkk (Stone et al, 2004) Inspirational motivation berarti karakter seorang pemimpin yang mampu menerapkan standar yang tinggi akan tetapi sekaligus mampu mendorong bawahan untuk mencapai standar tersebut. Karakter seperti ini mampu membangkitkan optimisme dan antusiasme yang tinggi dari pawa bawahan. Dengan kata lain, pemimpin transformasional senantiasa memberikan inspirasi dan memotivasi bawahannya.

Inspirational motivation menurut Humphreys (2002) serta Rafferty dan Griffin (20 04) memiliki korelasi yang erat dengan idealized influence. Seperti dijelaskan sebelumnya, pemimpin transformasional memberi inspirasi kepada bawahan untuk memusatkan perhatian pada tujuan bersama dan melupakan kepentingan pribadi. Inspirasi dapat diartikan sebagai tindakan atau kekuatan untuk menggerakkan emosi dan daya pikir orang lain (Rafferty \& Griffin, 2004).

Keeratan dua dimensi yaitu inspirational motivation dan idealized influence ini mendorong munculnya pandangan untuk menyatukan kedua dimensi ini dalam satu konstruk. Namun dalam penelitian ini, idealized influence dan inspirational motivation diposisikan sebagai dua konstruk yang berbeda dimana 
idealized influence mempunyai makna lebih dalam daripada inspirational motivation, atau dengan kata lain, inspirational motivation merupakan sisi luar atau perwujudan idealized influence (Humphreys, 2002; Rafferty \& Griffin, 2004).

Inspirational motivation menurut Humphreys (2002) berbentuk komunikasi verbal atau penggunaan simbol-simbol yang ditujukan untuk memacu semangat bawahan. Pemimpin memotivasi bawahanakan arti penting visi dan misi organisasi sehingga seluruh bawahannya terdorong untuk memiliki visi yang sama. Kesamaan visi memacu bawahan untuk bekerja sama mencapai tujuan jangka panjang dengan optimis. Sehingga pemimpin tidak saja membangkitkan semangat individu tapi juga semangat tim (Bass et.al., 2003).

\subsection{Stimulasi Intelektual $\left(\mathrm{X}_{3}\right)$ Berpengaruh Positif dan Signifikan terhadap Kinerja Pegawai (Y).}

Berdasarkan dari hasil penelitian terhadap 57 responden menunjukan bahwa secara parsial terdapat pengaruh langsung positif dan signifikan antara variabel stimulasi intelektual $\left(\mathrm{X}_{3}\right)$ terhadap kinerja pegawai $(\mathrm{Y})$ sebesar 0,105 atau $10,5 \%$. Hal ini menunjukan bahwa semakin ditingkatkan stimulasi intelektual $\left(\mathrm{X}_{3}\right)$ yang dilakukan oleh pimpinan maka akan semakin tinggi pula kinerja pegawai (Y) pada Dinas Pendidikan Kabupaten Bone Bolango. Hal ini disebabkan karena selalu menumbuhkan ide-ide yang baru, memberikan solusi kreatif terhadap berbagai permasalahan yang dihadapi oleh bawahannya, dan memberikan motivasi kepada bawahannya untuk mencari pendekatanpendekatan yang baru dalam melaksanakan tugas-tugas yang diberikan.

Menurut Avolio dkk (Stone et al, 2004) Intellectual stimulation merupakan suatu karakter seorang pemimpin transformasional yang mampu mendorong bawahannya untuk menyelesaikan permasalahan dengan cermat dan rasional. Selain itu, karakter ini mendorong para bawahan untuk menemukan cara baru yang lbih efektif dalam menyelesaikan masalah. Dengan kata lain, pemimpin transformasional mampu mendorong (menstimulasi) bawahan untuk selalu kreatif dan inovatif.

Intellectual stimulation, merupakan faktor penting kepemimpinan transformasional yang jarang memperoleh perhatian (Rafferty \& Griffin, 2004). Intellectual stimulation merupakan perilaku yang berupaya mendorong perhatian dan kesadaran bawahan akan permasalahan yang dihadapi. Pemimpin kemudian berusaha mengembangkan kemampuan bawahan untuk menyelesaikan permasalahan dengan pendekatanpendekatan atau perspektif baru. Dampak intellectual stimulation dapat dilihat dari peningkatan kemampuan bawahan dalam memahami dan menganalisis permasalahan serta kualitas pemecahan masalah (problem solving quality) yang ditawarkan (Rafferty \& Griffin, 2004; Yammarino et.al., 1993).

Menurut Bass et.al (2003) serta Sarros dan Santora (2001) berpandangan bahwa intellectual stimulation pada prinsipnya memacu bawahan untuklebih kreatif dan inovatif dalam memahami dan memecahkan masalah.Bawahan didorong untuk meninggalkan cara-cara atau metode-metodelama dan dipacu untuk memberikan ide dan solusi baru. Bawahan bebasmenawarkan metode baru dan setiap ide baru tidak akan mendapatkritikan atau celaan. Sebaliknya, pemimpin berusaha meningkatkanmoral bawahan untuk berani berinovasi. Pemimpin bersikap dan berfungsi membina dan mengarahkan inovasi dan kreativitas bawahan. 


\subsection{Konsiderasi Individu $\left(\mathrm{X}_{4}\right)$ Berpengaruh Positif dan Signifikan terhadap Kinerja Pegawai (Y).}

Berdasarkan dari hasil penelitian terhadap 57 responden menunjukan bahwa secara parsial terdapat pengaruh langsung positif dan signifikan antara variabel Konsiderasi individu $\left(\mathrm{X}_{4}\right)$ terhadap kinerja pegawai $(\mathrm{Y})$ sebesar 0,122 atau $12,2 \%$. Hal ini menunjukan bahwa semakin ditingkatkan Konsiderasi individu $\left(\mathrm{X}_{4}\right)$ yang dilakukan oleh pimpiunan maka akan semakin tinggi pula kinerja pegawai (Y) pada Dinas Pendidikan Kabupaten Bone Bolango. Hal ini disebabkan karena kepala dinas pada Dinas Pendidikan Kabupaten Bone Bolango yang mau mendengarkan dengan penuh perhatian masukan-masukan dari bawahannya dan secara khusus mau memperhatikan kebutuhankebutuhan bawahannya terhadap pengembangan karir.

Menurut Avolio dkk (Stone et al, 2004) Individualized consideration berarti karakter seorang pemimpin yang mampu memahami perbedaan individual para bawahannya. Dalam hal ini, pemimpin transformasional mau dan mampu untuk mendengar aspirasi, mendidik, dan melatih bawahan. Selain itu, seorang pemimpin transformasional mampu melihat potensi prestasi dan kebutuhan berkembang para bawahan serta memfasilitasinya. Dengan kata lain, pemimpin transformasional mampu memahami dan menghargai bawahan berdasarkan kebutuhan bawahan dan memperhatikan keinginan berprestas dan berkembang para bawahan

Individualized consideration atau perhatian pribadi. Individualized consideration mengarah pada pemahaman dan perhatian pemimpin pada potensi dan kemampuan yang dimiliki oleh setiap bawahannya. Pemimpin menyadari perbedaan kemampuan, potensi, dan juga kebutuhan bawahan. Pemimpin memandang setiap bawahannya sebagai aset organisasi. Oleh sebab itu, pemahaman pemimpin akan potensi dan kemampuan setiap bawahan memudahkannya membina dan mengarahkan potensi dan kemampuan terbaik setiap bawahan (Bass et.al., 2003; Sarros \& Santora, 2001; Yammarino et.al., 1993).

\section{PENUTUP}

\subsection{KESIMPULAN}

Berdasarkan hasil penelitian dan pembahasan yang telah diuraikan sebelumnya dapat ditarik kesimpulan yang berhubungan dengan Pengaruh Kepemimpinan Transformasional Terhadap Kinerja Pegawai di Dinas pendidikan Kabupaten Bone bolango adalah sebagai berikut:

a. Terdapat pengaruh langsung yang positif dan signifikan secara simultan antara variabel kepemimpinan transformasional terhadap kinerja pegawai di Dinas Pendidikan Kabupaten Bone Bolango. Hal ini di tentukan berdasarkan temuan penelitian yang dapat dikemukakan adalah adanya pengaruh langsung yang postif. Hal ini disebabkan karena pimpinan yang ada di Dinas Pendidikan Kabupaten Bone Bolango senantiasa berperilaku yang membuat bawahannya mengagumi, menghormati, dan sekaligus mempercayainya, mampu mengartikulasikan pengharapan yang jelas terhadap prestasi bawahan, mendemonstrasikan komitmennya terhadap seluruh tujuan organisasi, dan mampu mengunggah spirit tim dalam organisasi melalui penumbuhan antusiasme dan optimisme yang tinggi, menumbuhkan ide-ide baru, memberikan solusi kreatif terhadap berbagai 
permasalahan yang dihadapi bawahannya, dan memberikan motivasi kepada bawahannya untuk mencari pendekatan-pendekatan yang baru dalam melaksanakan tugas-tugasnya.

b. Terdapat pengaruh langsung yang positif dan signifikan antara variabel kepemimpinan idealized influence (pengaruh ideal) secara parsial terhadap kinerja pegawai pada Dinas Pendidikan Kabupaten Bone Bolango. Hal ini dikarenakan perilaku pimpinan pada dinas pendidikan kabupaten bone bolango selalu membuat para pengikutnya mengagumi teknik kepemimpinan kepala Dinas Pendidikan Kabupaten Bone Bolango, selalu menghormati masukan dan kritikan bawahannya, dan adanya sikap yang saling mempercayai antara atasan dan bawahan.

c. Terdapat pengaruh langsung yang positif dan signifikan antara variabel kepemimpinan motivasi inspirasisecara parsial terhadap kinerja pegawai pada Dinas Pendidikan Kabupaten Bone Bolango. Hal ini dikarenakan pimpinan dinas pendidikan mampu mengartikulasikan pengharapan yang jelas terhadap prestasi bawahannya, selalu mendemonstrasikan komitmen terhadap seluruh tujuan yang ingin dicapai oleh dinas pendidikan kabupaten bone bolango, dan mampu mengunggah spirit tim dalam organisasi melalui penumbuhan antusiasme dan optimisme yang tinggi terhadap bawahannya.

d. Terdapat pengaruh langsung yang positif dan signifikan antara variabel kepemimpinan stimulasi intelektualsecara parsial terhadap kinerja pegawai di Dinas Pendidikan Kabupaten Bone Bolango. Hal ini disebabkan karena selalu menumbuhkan ide-ide yang baru, memberikan solusi kreatif terhadap berbagai permasalahan yang dihadapi oleh bawahannya, dan memberikan motivasi kepada bawahannya untuk mencari pendekatan-pendekatan yang baru dalam melaksanakan tugastugas yang diberikan.

e. Terdapat pengaruh langsung yang positif dan signifikan antara kepemimpinan konsiderasi individu secara parsial terhadap kinerja pegawai di Dinas Pendidikan Kabupaten Bone Bolango. Hal disebabkan karena kepala dinas pada Dinas Pendidikan Kabupaten Bone Bolango yang mau mendengarkan dengan penuh perhatian masukan-masukan dari bawahannya dan secara khusus mau memperhatikan kebutuhankebutuhan bawahannya terhadap pengembangan karir.

\section{DAFTAR PUSTAKA}

Arikunto S, 2006. Prosedur Penelitian Suatu Pendekatan Praktik, Ed Revisi VI, Penerbit PT Rineka Cipta, Jakarta.

Anikma Widodo. 2008. Penelitian "Kepemimpinan Transformasional Terhadap Kinerja Pegawai di PT. Jati Agung”. Gresik.

Achmad sanusi. 2008. Kepemimpinan sekarang dan masa depan. Bandung: Prospect.

Avolio BJ, Zhu W, Koh W, Bhatia P, Stone et al, Refferty \& Griffin, Humphreys, Sarros \& Santora, Yammarino. 2004, Transformational leadership and organizational commitment: Mediating role of psychological empowerment and moderating role of structural distance. Journal Organization Behavior, 25(8):951-68 
Bass, BM \& Avolio B.J. 1990. Improving organizational effectiveness though transformasional leadership. Sage thousand oaks

Danim Sudarman. 2008. kinerja staf dan organisasi. Cv. Pustaka setia. Bandung

Danim Sudarman. 2004. Motivasi kepemimpinan dan efektivitas kelompok. PT. Rineka cipta. jakarta

Nirwana SK, 2004. Analisis Jalur (Path Analisis)

Robbins, Stephen P. 2000. Essenhals pf organizational bahaviior. Priintice hall internasional. New jersey.

Riduwan. 2013. Caramenggunakan dan memaknai Path Analysis (analisis jalur) Bandung. Penerbit Alfabeta

Rivai, Vaithzal. 2005. Kepemimpinan dan perilaku organisasi. Raja grafindo persada. Jakarta

Robbins Stephen P \& Mary Coulter. 1999. Manajemen. PT. Prenhallindo. Jakarta

Robbins, S. Dan Timothy A,J. 2010. Perilaku Organisasi. Jakarta: Salemba Empat. Edisi ke16.

Robbins, Stephen P. 2010. Perilaku Organisasional, Jilid I dan II. Salemba Empat: Jakarta.

Sinnambela Lijan poltak. 2014. Teori, kebijakan, dan implementasi. Cv. Alfabeta. Jakarta

Sedarmayanti. 2011. Membangun dan mengembangkan kepemimpinan serta meningkatkan kinerja untuk meraih keberhasilan. PT. Rafika aditama. Bandung

Sedarmayanti.2008 .sumber daya manusia dan produktivitas kerja. Rafika aditama. Bandung

Undang-undang nomor 23 tahun 2014 tentang pemerintahan daerah 